\title{
JUDICIAL REVIEW: NEPA AND THE COURTS
}

Growing public concern ${ }^{1}$ has resulted in the enactment of several significant statutes to control the needless degradation of our natural environment. ${ }^{2}$ Certainly "the broadest and perhaps nnost important" of these statutes ${ }^{3}$ is the National Environmental Policy Act of 1969 (NEPA). ${ }^{4}$ NEPA "takes the major step of requiring all federal agencies to consider values of environmental preservation in their spheres of activity . . .." In addition, the Act establishes operating procedures for all federal agencies to follow in planning activities which will have an impact on the environment. ${ }^{6}$ In order to comply with NEPA, an agency undertaking a inajor federal project which will have a significant impact on the environment inust prepare an environmental impact statement. ${ }^{7}$ The preparation of this statement will, in general terms, require the agency to imvestigate and study the impact of the proposed project

1. This concern is reflected in President Nixon's State of the Union Message:

Restoring nature to its natural state is a cause beyond party and beyond factions. It has become a common cause of all people of this country. It is the cause of particular concern to young Americans because they will reap the grim consequences of our failure to act on programs which are needed now if we are to prevent disaster later-clean air, clean water, open spaces. These should once again be the birtbright of every American. If we act now they can be. Address by President Nixon, Jan. 22, 1970, reprinted in N.Y. Times, Jan. 23,1970 , $\$ 1$, at 22, col. 4.

2. See, e.g., Environmental Education Act, 20 U.S.C. $\S \S 1531-36$ (1970); Clean Air Act, 42 U.S.C. $\$ \$ 1857-1857 l$ (1970); Water and Environmental Quality Improvement Act, id. \$\$ 4371-74 (1970); Federal Water Pollution Control Act, Pub. L. No. 92-500 (Oct. 4, 1972), reprinted in U.S. CoDe CoNG. \& AD. News 5288 (1972).

3. Calvert Cliffs' Coordinating Comm. v. AEC, 449 F.2d 1109, 1111 (D.C. Cir. 1971).

4. 42 U.S.C. $\$ \$ 4321-47$ (1970).

5. Calvert Cliffs' Coordinating Comm. v. AEC, 449 F.2d 1109, 1111 (D.C. Cir. 1971).

6. 115 Cong. Rec. 40416 (1969) (remarks of Senator Jackson). See generally Hanks \& Hanks, An Environmental Bill of Rights: The Citizen Suit and the National Environmental Policy Act of 1969, 24 RuTGERs L. REV. 230 (1970); Note, The National Environmental Policy Act: A Sheep in Wolf's Clothing?, 37 BROOKLYN L. Rev. 139 (1970); Note, A Panoramic View of the National Environmental Policy Act, 16 How. L.J. 116 (1970); Note, NEPA: Full of Sound and Fury . . . ., 6 U. RICHMOND L. REV. 116 (1971); 58 VA. L. REV. 177 (1972).

7. In preparing an impact statement, an agency is required to collect and study data rèlating to five factors set forth in NEPA. 42. U.S.C. $\$ \S 4332(2)$ (C) (i)-(v) (1970). For the full text of this portion of NEPA, see note 11 infra. 
on the environment, to consider alternatives to the proposed action, and to justify environmental costs if the decision is made to continue the project. The manner of preparation of these statements and the merits of the decisions made in light of the environmental studies have increasingly become the objects of judicial scrutiny. As one commentator has pointed out, "the restoration and maintenance of a livable environment is, to a large extent, the problem of the control of administrative agencies by the courts."

The ensuing discussion will focus on two major unresolved issues in the problem area of judicial scrutiny of administrative decisions affecting the environment: First, if an agency has fully counplied with NEPA requirements that an impact statement be prepared, did Congress intend that the actual decision of the agency on the merits be reviewed under the substantive provisions of NEPA? Second, if the decision is to be subject to judicial scrutiny, what is the standard of review?

\section{Judicial Review of Agency Decisions on the Merits Under Section 101}

Section 101 of NEPA broadly declares that it is a continuing federal policy and responsibility "to use all practicable means, consistent with other essential considerations of national policy" to achieve, maintain, and preserve a quality environment for the nation. $^{9} \quad$ Section 102 establishes what are commonly designated as

8. Sive, Some Thoughts of an Environmental Lawyer in the Wilderness of Administrative Law, 70 CoLum. L. REv. 612, 615 (1970). Congress also realized that federal agencies have a great impact on the environment: "Virtually every agency of the Federal Government plays some role in determining how well the environment is managed." S. ReP. No. 296, 91st Cong., 1st Sess. 9 (1969).

9. The ensuing discussion will focus on the specific language in $\S 101$ :

(a) The Congress, recognizing the profound impact of man's activity on the interrelations of all components of the natural environment, particularly the profound influences of population growth, high-density urbanization, industrial expansion, resource exploitation, and new and expanding technological advances and recognizing further the critical importance of restoring and maintaining environinental quality to the overall welfare and development of man, declares that it is the continuing policy of the Federal Government, in cooperation with State and local governments, and other concerned public and private organizations, to use all practicable ineans and measures, including financial and technical assistance, in a manner calculated to foster and promote the general welfare, to create and maintain conditions under which man and nature can exist in productive harmony, and fulfill the social, economic, and other requirements of present and future generations of Americans.

(b) In order to carry out the policy set forth in this chapter, it is the continuing responsibility of the Federal Government to use all practicable means, consistent with other essential considerations of national 
"action-forcing" procedures ${ }^{10}$ to implement the environmental goals of section $101 . .^{11}$ In litigation involving these sections of the Act, the courts have uniformly held that judicial review is available to

policy, to improve and coordinate Federal plans, functions, programs, and resources to the end that the Nation may-

(1) fulfill the responsibilities of each generation as trustee of the environment for succeeding generations;

(2) assure for all Americans safe, healthful, productive, and esthetically and culturally pleasing surroundings;

(3) attain the widest range of beneficial uses of the environment without degradation, risk to bealth or safety, or other undesirable and unintended consequences;

(4) preserve important historic, cultural, and natural aspects of our national heritage, and maintain, wherever possible, an environment which supports diversity and variety of individual choice;

(5) achieve a balance between population and resource use which will permit high standards of living and a wide sharing of life's amenities; and

(6) enhance the quality of renewable resources and approach the maximum attainable recycling of depletable resources.

(c) The Congress recognizes that each person should enjoy a healthful environment and that each person has a responsibility to contribute to the preservation and enhancement of the environment. 42 U.S.C. $\$ 4331$ (1970).

10. S. REP. No. 296, 91st Cong., 1st Sess. 9 (1969). The "action-forcing" procedures are statutory provisions designed to assure that the agencies plan and work toward maintaining and enhancing our environment. Id. Basically, the provisions consist of procedural requirements that an agency utilize the social sciences in planning a project, develop methods to quantify environmental cost, prepare impact statements, and cooperate with state and local governinent and with the Council on Environmental Quality, 42 U.S.C. $\$ 4332$ (1970). For a portion of the text of this statute, see note 11 infra.

11. 42 U.S.C. $\$ 4332$ (1970) provides in part:

The Congress authorizes and directs that, to the fullest extent possible: (1) the policies, regulations, and public laws of the United States shall be interpreted and administered in accordance with the policies set forth in this chapter, and (2) all agencies of the Federal Government shall-

(A) utilize a systematic, interdisciplinary approach which will insure the integrated use of the natural and social sciences and the environmental design arts in planning and in decisionmaking which may have an impact on man's environment;

(B) identify and develop inethods and procedures, in consultation with the Council on Environmental Quality established by subchapter II of this chapter, which will insure that presently unquantified environmental amenities and values may be given appropriate consideration in decisionmaking along with economic and technical considerations;

(C) include in every recommendation or report on proposals for legislation and other major Federal actions significantly affecting the quality of the human environment, a detailed statement by the responsible official on-

(i) the environmental impact of the proposed action,

(ii) any adverse environmental effects which cannot be avoided should the proposal be implemented,

(iii) alternatives to the proposed action,

(iv) the relationship between local short-term uses of man's environment and the maintenance and enhancement of long-term productivity, and

(v) any irreversible and irretrievable commitments of resources which would be involved in the proposed action should it be implemented. 
determine whether an agency has fully complied with the "actionforcing" procedural requirements of section 102. ${ }^{12}$ However, no such judicial uniformity exists on the issue of whether there is sub. stantive review of an agency decision under section 101. A fundamental conflict exists between courts as to the nature and effect of section 101 and as to the judicial role in reviewing agency decisions under this section. ${ }^{13}$

Substantive Review: Two Views. Two contradictory lines of reasoning pervade the case law on the question of whether NEPA permits courts to review the inerits of an agency decision. The reasoning of those courts which refuse to make such a review is most cogently presented in the 1971 decision by the District Court for the Eastern District of Arkansas, Environmental Defense Fund, Inc. v. Corps of Engineers. ${ }^{14}$ Environmental Defense Fund (EDF) sought to enjoin the construction of the Gillham Dam across the Cossatot River in Arkansas. Although unpersuaded by much of the reasoning einbodied in the Corps' impact statement, ${ }^{15}$ the district court nevertheless held that no reasonable interpretation of NEPA would allow review of the agency decision on the inerits under the policies set forth in section $101 .^{16}$

As the district court viewed the problem, the ultimate decision as to whether to pursue a project must be made by the agency. Substantive review, the court concluded, would result in the judiciary's substituting its judgment for that of the agency:i7 therefore, plaimtiffs were relegated to inere review of procedural compliance

12. See, e.g., Save Our Ten Acres v. Kreger, 472 F.2d 463 (5th Cir. 1973); Environmental Defense Fund, Inc. v. Corps of Eng'rs, 470 F.2d 289 (8th Cir. 1972); Scherr v. Volpe, 466 F.2d 1027 (7th Cir. 1972); Hanly v. Mitchell, 460 F.2d 640 (2d Cir.), cert. denied, Hanly v. Kleindienst, 409 U.S. 990 (1972); Calvert Cliffs' Coordinating Comm. v. AEC, 449 F.2d 1109 (D.C. Cir. 1971); Daly v. Volpe, 350 F. Supp. 252 (W.D. Wash. 1972); Note, Evolving Judicial Standards Under the National Environmental Policy Act and the Challenge of the Alaska Pipeline, 81 YALE L.J. 1592 (1972).

13. See note 20 infra and accompanying text.

14. 325 F. Supp. 749 (E.D. Ark. 1971) (maintaining injunction against construction of dam). This injunction was dissolved in Euvironmental Defense Fund, Inc. v. Corps of Eng'rs, 342 F. Supp. 1211 (E.D. Ark.), aff'd on other grounds, 470 F.2d 289 (8th Cir. 1972).

15. 325 F. Supp. at 760-62. See note 68 infra.

16. Environmental Defense Fund, Inc. v. Corps of Eng'rs, 325 F. Supp. 728, 738 (E.D. Ark. 1970).

17. 325 F. Supp. at 755. Accord, Conservation Council v. Froehlke, 340 F. Supp. 222, 228 (M.D.N.C. 1972), rev'd, - F.2d - (4th Cir. 1973) (per curiam). 
with the Act. ${ }^{18}$ The district court thus viewed NEPA as a full disclosure law, requiring only strict procedural compliance. ${ }^{19}$ Since the 1971 decision in Environmental Defense Fund, numerous courts have specifically followed this reasoning. ${ }^{20}$

The second line of cases $^{21}$-decisions which have indicated or

18. 325 F. Supp. at 755. Accord, Conservation Council v. Froeblke, 340 F. Supp. 222, 225 (M.D.N.C. 1972), rev'd, - F.2d - (4th Cir. 1973) (per curiam); Bucklien v. Volpe, 2 BNA ENVIRONMBNT REP. - CAS. 1082, 1083 (N.D. Cal. 1970).

19. 325 F. Supp. at 755. Accord, Conservation Council v. Froehlke, 340 F. Supp. 222, 225 (M.D.N.C. 1972), rev'd, - F.2d - (4th Cir. 1973).

20. The reasoning and judicial approach reflected in the district court opinion have been cited and adopted by many other courts. See Bradford Township v. Illinois State Toll Highway Authority, 463 F.2d 537 (7th Cir.), cert. denied, 41 U.S.L.W. 3313 (U.S. Dec. 5, 1972); McQueary v. Laird, 449 F.2d 608 (10th Cir. 1971); Pizitz v. Volpe, 4 BNA Environmental Rep.-Cas. 1195 (M.D. Ala.), affed mem. 467 F.2d 208 (5th Cir. 1972); Environmental Defense Fund, Inc. v. Corps of Eng'rs, 348 F. Supp. 916 (N.D. Miss. 1972); Bucklien v. Volpe, 2 BNA ENvIRoNMENTAL REP.-CAs. 1082 (N.D. Cal. 1970).

The Fifth Circuit's position is unclear. Although it affirmed per curiam the district court holding that there is no substantive review, Pizitz v. Volpe, 467 F.2d 208 (5th Cir. 1972), the Court of Appeals for the Fifth Circuit has never squarely confronted this issue. In Save Our Ten Acres v. Kreger, 472 F.2d 463, 467 (5th Cir. 1973), the court stated

that it is not the province of the courts to review any actual decision on the merits ... as to the desirability vel non of the project. We merely hold that it is the courts' function to insure that the mandate of the statute has been carried out and that all relevant environmental effects of the project be given appropriate consideration ....

However, in Zabel v. Tabb, 430 F.2d 199, 211 (5th Cir. 1970), the court said that [t]his Act essentially states that every federal agency shall consider ecological factors when dealing with activities which nay have an impact on inan's environment.

In both of these cases, the court was concerned with other sections of the Act; and these statements are dicta.

21. Several other courts have held that there is substantive review under $\$ 101$. See Environinental Defense Fund, Inc. v. Froehlke, - F.2d - (8th Cir. 1972); National Resources Council, Inc. v. Morton, 485 F.2d 827 (D.C. Cir. 1972); Scenic Hudson Preservation Conference v. FPC, 453 F.2d 463 (2d Cir.), cert. denied, 407 U.S. 926 (1972); City of New York v. United States, 344 F. Supp. 929 (E.D.N.Y. 1972); Lathan v. Volpe, 350 F. Supp. 262 (W.D. Wash. 1972).

Until recently the Fourth Circuit's position was unclear. In Ely v. Velde, 451 F.2d 1130 (4th Cir. 1971), the court imitially indicated that it would allow substantive review. Then, after a period of some confusion, the Fourth Circuit held that there was substantive review under section 101 of NEPA. Conservation Council v. Froehlke, - F.2d - (4th Cir. 1973) (per curiam), rev'g 340 F. Supp. 222 (M.D.N.C. 1972).

Furthermore, the Council on Environmental Quality, in its third annual report, stated:

NEPA commands firmly that an agency must, to the fullest extent possible, take environmental values into account .... If an agency fails ... it can be ordered to comply by a court. But neither NEPA's substantive duty nor its 102 process purports to dictate the agency's choice of a course 
held that NEPA permits substantive judicial review-is most clearly illustrated by the Eighth Circuit's decision in Environmental Defense Fund, Inc. v. Corps of Engineers. ${ }^{22}$ The court of appeals, which rejected the lower court's analysis, reasoned that "NEPA was intended to effect substantive changes in decision making." ${ }^{23}$ The Act commands the agency to balance environmental factors against the economic and technical factors involved in each project; therefore, the court concluded, since the agencies had an "obligation" to carry out the substantive requirements of NEPA, the "courts have an obligation to review ... agency decisions on the merits." 24

Substantive Review: Analysis. Section 10 of the Administrative Procedure Act (APA) provides the basic franework for a determination of whether a given statute permits substantive judical review. ${ }^{25}$ Section 10 entitles a person adversely affected or aggrieved by agency action to judicial review" ${ }^{26}$ "except to the extent that (1) statutes preclude judicial review; or (2) agency action is committed to agency discretion by law."27 Construmg this statute, the Supreme Court has found that the APA has a broad remedial purpose; this purpose, the Court has indicated, counsels judicial hospitality to the claim that section 10 has expanded the availability of judicial review. ${ }^{28}$

The landmark decision defining the scope of the first exception to judicial review of agency actions-that is, review precluded by statute-is Abbott Laboratories v. Gardner. ${ }^{20}$ The Court, reiter-

of action. . . . The courts have uniformly said that, after an agency has considered environmental effects, its decision to act is subject to limited judicial review .... 3 COUNCIL ON ENVIRONMENTAL QUALITY ANN. REP. 253-54 (1972).

22. 470 F.2d 289 (8th Cir.), aff'g on other grounds, 342 F. Supp. 1211 (E.D. Ark. 1972).

23. Id. at 297.

24. Id. at 298.

25. 5 U.S.C. $\$ \$ 701-06$ (1970). The APA applies to "each authority" of the federal government except certain enumerated authorities such as Congress, federal courts, courts-martial, and territorial governinents. Id. $\$ 551(1)$. None of these exceptions are relevant to the discussion in the text nor to the application of NEPA.

26. Id. $\S 702$.

27. Id. $\S 701$.

28. Heikkila v. Barber, 345 U.S. 229, 232-33 (1953). See Association of Data Processing Serv. Organizations, Inc. v. Camp, 397 U.S. 150, 156 (1970); Rusk v. Cort, 369 U.S. 367, 379-80 (1962); Shaughnessy v. Pedreiro, 349 U.S. 48, 51 (1954).

29. 387 U.S. 136 (1967). 
ating that the APA provides generously for judicial review, held that "review of a final agency action . . . will not be cut off unless there is persuasive reason to believe that such was the purpose of Congress." ${ }^{30}$ Court decisions reflect a strong presumption that final agency action is reviewable absent express statutory language to the contrary. ${ }^{31}$ Furthermore, where the statute explicitly precludes judicial review, the courts laave, on occasion, narrowly construed the precluding language, ${ }^{32}$ thus, even statutory provisions stating that the agency action is final have often been held not to bar judicial review. ${ }^{33}$ There clearly is no language in NEPA which expressly precludes judicial review. ${ }^{34}$

Absent an express statutory denial of judicial review, courts will not restrict access to judicial review unless a contrary legislative intent is shown by "clear and convincing evidence." 35 In fact, Professor Jaffe has said that "at least in the post-APA statutes, it requires . ... a statutory provision explicitly directed to the exclusion of judicial review to rebut the presumption of the APA in fa-

30. Id. at 140. See Citizens To Preserve Overton Park, Inc. v. Volpe, 401 U.S. 402, 410 (1971); Association of Data Processing Serv. Organizations, Inc. v. Camp, 397 U.S. 150, $156-57$ (1970); Barlow v. Collins, 397 U.S. 159, 166-67 (1970); Brownell v. We Shung, 352 U.S. 180, 185 (1956). See also Davis $§ 28.08$, at 33; JAFFE 353-76.

31. JAFFE 353. See note 30 supra.

32. See Tracy v. Gleason, 379 F.2d 469 (D.C. Cir. 1967); Thompson v. Gleason, 317 F.2d 901 (D.C. Cir. 1962); Electric Motors, Inc. v. Jones, 153 F.2d 134 (D.C. Cir. 1946). But see Milliken v. Gleason, 332 F.2d 122 (1st Cir. 1964), cert. denied, 397 U.S. 1002 (1965); Sinkio v. United States, 271 F.2d 846 (D.C. Cir. 1959); French v. War Contracts Price Adjustment Bd., 182 F.2d 560 (9th Cir. 1950).

33. See Oestereich v. Selective Serv. Bd. No. 11, 393 U.S. 233 (1968); Estep v. United States, 327 U.S. 114 (1946); Wolff v. Selective Serv. Bd. No. 16, 372 F.2d 817 (2d Cir. 1967); DAVIS $\$ \S 28.10,28.12$; JAFFE 356.

34. In fact, an argument can be made that the statute contemplates review of agency decisions made pursuant thereto. Section 102(1) of NEPA "directs that, to the fullest extent possible: (1) the policies, regulatious, and public laws of the United States shall be interpreted and administered in accordance with the policies set forth in this chapter ..." 42 U.S.C. $\$ 4332$ (1970) (emphasis added). Unlike the procedural requirements of section $102(2)$ which is specifically directed to agencies, the language of section $102(1)$ is not so limited. Furthermore, the word "interpreted," found in section $102(1)$, is a term normally associated with judicial interpretation of statutes. From the fact that section $102(1)$ is not expressly limited to agencies and from the fact that section 102(1) requires that the laws be interpreted in accordance with the policies of section 101, it can be inferred that NEPA, instead of precluding review, actually contemplates it.

35. Abbott Laboratories v. Gardner, 387 U.S. 136, 139-41 (1967), quoting Rusk v. Cort, 369 U.S. $367,379-80$ (1962). 
vor of review."36 Just as the statutory language is silent as to the precluding of judicial review, the legislative history contains no evidence whatsoever showing a congressional intent to foreclose judicial review of agency decisions under section 101 of NEPA. ${ }^{37}$

The second area of agency activity excepted frow judicial review under section 10 of the APA is action committed to agency discretion by law. ${ }^{38}$ The Supreme Court has considered the application of this exception ${ }^{39}$ and has cautioned that

[t]his is a very narrow exception. The legislative history of the [APA] indicates that it is applicable in those rare instances where "statutes are drawn in such broad terms that in a given case there is no law to apply." 40

Therefore, the question is whether in section 101 there is "law to apply."

The landmark decision on this question is Citizens to Preserve Overton Park, Inc. v. Volpe. ${ }^{41}$ In Overton Park the plaintiffs contended that the Secretary of Transportation had exceeded his statutory authority by authorizing the expenditure of federal funds for the construction of a highway through a park. The statutes in question provided that the Secretary shall not approve any highway program or project which requires the use of any parkland "unless (1) there is no feasible and prudent alternative to the use of such land, and (2) such program includes all possible planning to mimimize harm to such park . . .."2 The Court, narrowly constru-

36. JAFFe 374. But see Davis $\$ 28.08$.

37. The legislative history clearly indicates that section 102(1), in conjunction with the goals set forth in section 101, was intended to make substantive changes in decision making. See S. REP. No. 296, supra note 8, at 19-20. Just as the procedural changes mandated by section $102(2)$ are subject to judicial review, the substantive changes mandated by section 102(1) should be subject to judicial review.

38. See text accompanying note 27 supra.

39. Citizens To Preserve Overton Park, Inc. v. Volpe, 401 U.S. 402 (1971). Before the Supreme Court considered this exception in Overton Park, a fierce academic battle had raged between Professors Davis, Berger, and Saferstein as to the correct interpretation of the statute. See, e.g., Berger, Administrative Arbitrarlness: A Synthesis, 78 YALE L.J. 965 (1969); Berger, Administrative Arbitrariness and Judicial Review, 65 Colum. L. Rev. 55 (1965); Davis, Administrative Arbitrariness is Not Always Reviewable, 51 MrNN. L. Rev. 643 (1967); Saferstein, Nonreviewability: A Functional Analysis of "Committed to Agency Discretion," 82 HARV. L. REv. 367 (1968).

40. Citizens to Preserve Overton Park, Inc. v. Volpe, 401 U.S. 402, 410 (1971) (citations omitted).

41. 401 U.S. 402 (1971).

42. Federal-Aid Highway Act, 23 U.S.C. $\& 138$ (1970) (emphasis added); Department of Transportation Act, 49 U.S.C. $\$ 1653$ (f) (1970) (emphasis added). 
ing the statutory language of these acts, ${ }^{43}$ rejected the view that the statutes were merely directives not intended to limit the Secretary's discretion. ${ }^{44}$ Noting that the statutes limited the Secretary's discretion, ${ }^{45}$ and implicitly recognizing that the reviewing court inust ascertain whether the administrator has acted within that narrowed discretion, ${ }^{46}$ the Court ruled that "plainly there is 'law to apply."

An analysis of the Court's reasoning in Overton Park reveals that there will be "law to apply" if the statute in question limits or alters an administrator's discretion and is not merely a statute which authorizes the discretionary consideration of statutory factors in the decision-unaking process. ${ }^{48}$ As noted ${ }^{49}$ in Environmental Defense Fund the court of appeals concluded that, im light of the statutory language and legislative history, NEPA inandates substantive changes in decision-1naking ${ }^{50}$ - commanding that national environmental goals be given weight in the ultimate agency decision..$^{51}$ The legislative history also indicates that, despite the broad language of the environinental goals, ${ }^{52}$ these goals were defined in "operational terms"53 so that the agencies and courts could consider and act upon them. ${ }^{54}$ Thus, Congress "desired a reordering of priorities,

43. For discussion of the legislative history and the strict construction which the Supreme Court gave to the statutes, see The Supreme Court, 1970 Term, 85 HARV. L. REv. 315 (1972); 1971 Duke Project 317.

44. 401 U.S. at $412 \&$ n.28.

45. $1 d$. at 411-13.

46. See id. at 416.

47. Id. at 413. The Court held that the Secretary could approve the use of parkland for highway construction only where "truly unusual factors were present in a particular case if the cost or community disruption resulting from alternative routes reached extraordinary magnitudes." Id.

48. For a fuller discussion of the concept of "law to apply," see Supreme Court, 1970 Term, 85 HaRv. L. REv. 315, 316-18 (1971); 60 GEO. L.J. 1101 (1972).

49. See notes 22-24 supra and accompanying text.

50. 470 F.2d at 297 . See notes $22-24$ supra and accompanying text.

51. 470 F.2d at 298.

52. The legislative history indicates that:

[a] statement of national policy for the environment-like other major policy declarations-is in large measure concerned with principle rather than detail; with an expression of broad national goals rather than narrow and specific procedures for implementation. S. REP. No. 296, supra note 8 , at 9 .

53. Id. at 13.

54. Id. Senator Jackson, sponsor of NEPA in the Senate, declared during discussion of the measure:

A statement of environmental policy is more than a statement of what we beheve as a people and as a nation. It establishes priorities and gives expression to our national goals and aspirations. It provides a statutory foundation to which administrators may refer ... for guidance in making decisions which find environmental values in conflict with other values. 
so that environmental cost and benefits will assume their proper place along with other considerations." 55 To the extent that NEPA requires agencies to reorder priorities and give weight to environmental considerations, the Act demands a substantive change in agency decision-making and constrains the exercise of discretion. These changes and limitations provide the necessary "law to apply" and permit the courts to review the merits of agency decisions in order to assure that those decisions are made within the now narrowed scope of discretion under the agency's authorizing statute.

\section{Standard of Judicial Review}

In the absence of an express statutory standard of judicial review to be applied to substantive agency decisions under NEPA, courts have varied in their selection of a proper standard. ${ }^{56}$ Two recent major cases typify the differing approaches.

Standards of Review Applied Under Section 101. In Cal-

115 CONG. REC. 40416 (1969).

Also see id. at 19009 (remarks of Senator Jackson). He further stated:

If an environmental policy is to become more than rhetoric, and if the studies and advice of any high-level, advisory group are to be translated into action, each of these agencies must be enabled and directed to participate in active and objective-oriented environmental management. Concern for environmental quality must be made part of every phase of Federal Action. Id. at 29087.

55. Calvert Cliffs' Coordinating Comm. v. AEC, 449 F.2d 1109, 1112 (D.C. Cir. 1971). Accord, Environmental Defense Fund, Inc. v. Corps of Eng'rs, 470 F.2d 289 (8th Cir. 1972); Scherr v. Volpe, 466 F.2d 1027 (7th Cir. 1972). Senator Jackson has expressed the same view. See note 54 supra.

56. The Court of Appeals for the Fourth Circuit, in Conservation Council v. Froehlke, - F.2d -, - (4th Cir. 1973), rev'g 340 F. Supp. 222 (M.D.N.C. 1972), ruled that substantive review of agency decisions under NEPA is limited to determining whether the agency reached its decision after a full, good faith consideration of environmental factors and whether the actual decision reached was arbitrary and capricious or clearly gave insufficient weight to environmental factors. Accord, Environmental Defense Fund, Inc. v. Froehlke, - F.2d - (8th Cir. 1972).

In City of New York v. United States, 344 F. Supp. 929 (E.D.N.Y. 1972) (dictum), the court noted that substantive review under NEPA is extremely limited. The court seriously doubted that the agency decision should be reviewed under a substantial evidence test; rather, the arbitrary and capricious standard of rcview, which is more limited, appeared appropriate. Id. at 939-40. Accord, Calvert Cliffs' Coordinating Comm. v. AEC, 449 F.2d 1109, 1113 (D.C. Cir. 1971).

The Court of Appeals for the Second Circuit, in Scenic Hudson Preservation Conference v. FPC, 453 F.2d 463, 469 (2d Cir.), cert. denied, 407 U.S. 926 (1972), utilized a substantial evidence test in reviewing an agency decision. However, since the impact statemeut in this case was prepared in conjunction with an adjudicatory hearing on the same issues mandated by another statute, id. at 465 , the court's view as to the proper standard for NEPA decisions alone must be viewed as unclear. 
vert Cliffs' Coordinating Committee v. $A E C,{ }^{57}$ the Court of Appeals for the District of Columbia Circuit indicated that, although the judiciary has the power and duty to review the correctness of an agency decision, "reviewing courts probably cannot reverse a substantive decision on its merits, under section 101, unless it be shown that the actual balance of costs and benefits that was struck was arbitrary or clearly gave insufficient weight to environmental values." The court reasoned that, unlike the inherently inflexible and rigorously enforced procedural requirements of section $102,,^{59}$ the substantive policies of section 101 are flexible because the agency in pursuit of its objectives has only to "use all practicable means, consistent with other essential considerations of national policy."Bo Therefore, section 101 "leaves room for responsible exercise of [agency] discretion" to balance environmental costs against economic and technical considerations. ${ }^{61}$ The agency's balancing of these factors can only be set aside, the court concluded, if the result is "arbitrary and capricious."

Environmental Defense Fund, Inc. v. Corps of Engineers, ${ }^{63}$ a 1972 case decided by the Court of Appeals for the Eighth Circuit, agreed with the Calvert Cliffs' conclusion that the actual agency decision could be set aside only if the decision were arbitrary or capricious. ${ }^{64}$ However, the Environmental Defense Fund court felt that an additional inquiry was essential: Was the decision within the scope of the agency's authority as limited by NEPA? ${ }^{65}$ Under this bifurcated test, the reviewing court must first determine whether the agency had "reached its decision after a full, good faith consideration and balancing of environmental factors,"66 second,

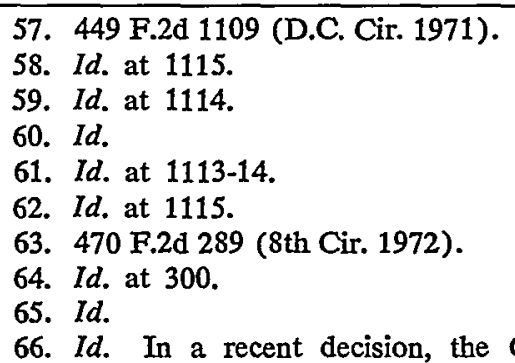

66. Id. In a recent decision, the Court of Appeals for the Eighth Circuit again held that there was substantive review of agency decisions under section 101 of NEPA. The court, while reiterating the same test as set forth in the EDF decision, stated that the agency decision could only be substantively reviewed under an arbitrary and capricious standard. Environmental Defense Fund, Inc. v. Froehlke, - F.2d - (8th Cir. 1972). The portion of the Eighth Circuit's recent decision setting forth the two-level test was recently quoted and cited by the Fourth Circuit in holding that there was substantive review under NEPA. Conservation 
the court must decide whether the balance of cost and benefits as the agency found them clearly gave insufficient weight to environmental factors or was arbitrary and capricious. ${ }^{\circ 7}$ The Eighth Circuit summarily balanced the benefits to be derived from flood control in this project against the detriment of a less diversified environment. Taking this balancing into account, the Environmental Defense Fund court concluded that the agency decision was not arbitrary and capricious. ${ }^{68}$

Standard of Review: Analysis. In the absence of a statutory provision specifying a particular standard of review, the APA provides a basic framework for judicial review. Section 706(2)(A)

Council v. Froehlke, - F.2d - (4th Cir. 1973), rev'g 340 F. Supp. 222 (M.D.N.C. 1972).

67. $470 \mathrm{~F} .2 \mathrm{~d}$ at 300 .

68. Id. at 301. The factors weighing in favor of completion included benefits to be derived from flood control and the fact that the project was already 63 per cent completed. Opposing these benefits was the detriment of a less diversified environment. However, the ineffectiveness of this test can be seen by reviewing the district court judge's findings of fact and unwillingness to believe the Corps' impact statement. Judge Eisele said:

The impact statement concludes that the project will have the effect of enhancing the water quality of the Cossatot. The plaintiffs' evidence, which is persuasive, indicates that the quality of the water of the Cossatot in its natural state could hardly be improved upon. . . .

The environmental impact statement suggests that the project will result in enhanced fish and wildlife benefits. A value judginent here depends upon the yardstick used, but plaintiffs have made a substantial showing that impoundment will result in a downstream eco-system that is less diverse and less stable .... The testimony also convinces the Court that the einbankment, while it might not decrease the total volume of fish life, will reduce the quality and the variety of fish life . . . .

Environmental Defense Fund, Inc. v. Corps of Eng'rs, 325 F. Supp. 728, 746-47 (E.D. Ark. 1971). See also 325 F. Supp. at 760-62 (illustrating more instances in which the judge, although considering himself powerless, disagreed with the Corps' conclusions).

Professor Jaffe has noted:

A prime function of the courts is to give these values an operative form. Thus, courts should conclude that a serious environmental impact must be justified by relevant and weighty considerations. This is, in a sense, a burden-of-proof rule, and we know that a skillful manipulation of such burdens can be decisive. Jaffe, Book Review, 83 HARV. L. REv. 1562, 1564 (1971).

In Scenic Hudson Preservation Conference v. FPC, 407 U.S. 926, denying cert. to 453 F.2d 463 (2d Cir. 1970), Justice Douglas asserted in his dissent:

Although value judgments are inevitable and even though the Commission's balancing of environmental costs with other factors may be entitled to some deference, I share Judge Timbers' doubts that under $\S 101$ the balance struck by an agency unskilled in environmental matters should be reviewed only through the lens of the "substantial evidence" test. Id. at 931 (dissenting opimion).

The rest of the discussion in this section will concern one possible way in which the courts can control administrative decisions affecting the environment. 
of the APA provides that a court can set aside agency action which is arbitrary, capricious, or an abuse of discretion..$^{69}$ As to this standard of review, both the Calvert Cliffs' court and the EDF court are in agreement. ${ }^{70}$ However, the APA also provides in section 706 (2)(C) that agency action may be set aside if that action is in excess of statutory authority or jurisdiction. ${ }^{71}$

In Overton Park, the Supreme Court carefully examined the scope and application of these provisions. As noted, ${ }^{72}$ the Court found that the statutes imvolved had severely limited the Secretary's discretion with regard to the use of parkland for road construction. The Court interpreted the statutes as giving the preservation of parkland paramount importance and as severely limiting the range of choices that the Secretary could make. ${ }^{73}$ To review the propriety of the Secretary's decision, the Court formulated a bifurcated standard of review. The first level of the test refers to the situation set forth in section 706(2)(C) of the APA-action taken in excess of statutory authority. ${ }^{74}$ The determination of whether the Secretary acted within his authority

naturally begins with a delineation of the scope of the Secretary's authority and discretion .... A Also involved in this initial inquiry is a determination of whether on the facts the Secretary's decision can reasonably be said to be within that range. The reviewing court must consider whether the Secretary properly construed his authority . . . . . ${ }^{75}$

Therefore, application of the first-level test to agency action under NEPA must begin with a determination of the degree to which NEPA now limits an agency's discretion. ${ }^{76}$

69. 5 U.S.C. $\$ 706(2)(\mathrm{A})(1970)$.

70. See text accompanying notes 58,67 supra.

71. 5 U.S.C. \& 706(2)(C) (1970).

72. See notes 41-46 supra and accompanying text.

73. 401 U.S. at 416 . For a discussion of the narrow range of choices left the Secretary, see 1971 Duke Project 317; 60 GEo. L.J. 1101 (1972).

74. 401 U.S. at 415.

75. Id. at 415-16 (emphasis added).

76. In Overton Park, the Supreme Court's interpretation of the statutes involved left the Secretary with only a small range of permissible choices. See text accompanying note 73 supra. However, the fact that under NEPA an agency has a wider range from which to choose does not mean that any given choice is within that range. The Secretary was prohibited from approving funds unless certain conditions were fulfilled: The fact that his authority was limited in a negative waythat is, he could not spend money unless he found certain conditions to existshould not be an important distinction. The Supreme Court indicated that the determination of whether the Secretary was within his authority begins with de- 
Section 101 of NEPA states that it is a continuing federal responsibility "to use all practicable means, consistent with other essential considerations of national policy" 77 to achieve six enumerated environmental goals. ${ }^{78}$ This phrase led the Calvert Cliffs' court to the conclusion that, unlike the inflexible procedural requirements of section 102(2) which nust be complied with to the "fullest extent possible," the substantive policies of NEPA are flexible. ${ }^{79}$ However, the imperative language of section 102(1) requires that the agencies "shall" "to the fullest extent possible . . . administer" their laws in accordance with the policies set forth in NEPA. ${ }^{80}$ The phrase "to the fullest extent possible," applies to both subsections 102(1) and 102(2), has been narrowly construed to inean "the fullest extent unless there is a clear conflict of statutory authority." 82 Thus, a more balanced reading of section 101 in conjunction with section 102 would require agencies, "to the fullest extent possible," "to use all practicable means, consistent with other essential considerations of national policy," in order to achieve a quality environment. Therefore, the flexibility that Calvert Cliffs' found was permitted by the "practicable means" language of section 101(b) is limited by the language "to the fullest extent possible" of section 102(1). ${ }^{83}$

fining the scope of his authority. See text accompanying note 75 supra. Thus, a positive grant of circumscribed authority should be indistinguishable from a withholding of authority unless certam conditions are met. One court has so held in a different factual context. Save Our Ten Acres v. Kreger, 472 F.2d 463, 466 (5th Cir. 1973).

77. 42 U.S.C. $\& 4331$ (b) (1970) (emphasis added). For the full text of this section, see note 9 supra.

78. 42 U.S.C. $\$ \S 4331$ (b)(1)-(6) (1970). For the full text of this section, see note 9 supra.

79. See text accompanying notes 59-60 supra.

80. 42 U.S.C. $\& 4332$ (1970) (emphasis added). For the full text of this section, see notc 11 supra.

81. 42 U.S.C. \& 4332 (1970).

82. Calvert Cliffs' Coordinating Comm. v. AEC, 449 F.2d 1109, 1115 (D.C. Cir. 1971). Accord, Scherr v. Volpe, 466 F.2d 1027 (7th Cir. 1972); Ely v. Velde, 451 F.2d 1130 (4th Cir. 1971).

Further, Senator Jackson, one of the sponsors of NEPA, has stated:

If there are to be departures froin this standard of excellence they should be the exceptions to the rule and the policy. And as exceptions, they will have to be justified in light of public scrutiny as reqnired by section 102 . 115 CONG. REC. 40416 (1969).

See 36 Fed. Reg. 7724 (1970) (guidelines issued by the Council on Environmental Quality).

83. Compare Warren \& Cohen, Judicial Recognition of the Substantive Require- 
The effect of the "practicable means" clause of section 101(b), however, is unlike that of the statutes construed in Overton Park. ${ }^{84}$ As the Calvert Cliffs' court correctly pointed out, NEPA provides only for a reordering of priorities and does not make environmental concerns an exclusive goal. ${ }^{85}$ Thus, an agency or administrator under NEPA has a somewhat broader range of choices than did the Secretary in Overton Park. Nevertheless, an agency still must use "all practicable means, consistent with other essential considerations of national policy . . . "86 This analysis is neither the same as balancing environmental costs agaimst economic and technical considerations of construction, as suggested in Calvert Cliffs, ${ }^{87}$ nor the same as balancing the benefits to accrue from a dam as against the environmental consequences, as was done in $E D F{ }^{88}$ The approach reflected in these two decisions is a balancing of benefits and detriments of an individual project; NEPA, however, requires the government to use all practicable means to achieve the environmental goals of section 101(b) consistent with other essential considerations of national policy. ${ }^{89}$

According to this analysis, the proper standard of review under NEPA would be the bifurcated test of Overton Park. First, as $E D F$ and Calvert Cliffs' point out, ${ }^{90}$ there should be a balancing of the benefits to be gained against the damage to be caused by any individual project. ${ }^{91}$ Second, a determination 1nust be inade as to whether the national policy in favor of environmental protection predominates over the national policy or policies to be served by

ments of the National Environmental Policy Act of 1969, 13 B.C. IND. \& COM. L. Rev. 685 (1972).

84. See notes $41-46,72-73$ supra and accompanying text.

85. See note 55 supra and accompanying text.

86. 42 U.S.C. $\$ 4331$ (b) (1970) (emphasis added). For the full text of this section, see note 9 supra.

The section-by-section analysis in the pertinent Senate report also states:

Wherever adverse environmental effects are found to be involved

.... a finding must be made that the action leading to the adverse en-

vironmental effects is justified by other considerations of national policy

- . . S. ReP. No. 296, supra note 8, at 20.

87. See text accompanying note 61 supra.

88. See text accompanying note 68 supra.

89. Compare 42 U.S.C. $\$ 4332(2)$ (B) (1970). For the full text of this section of the Act, see note 11 supra.

90. See notes 61,68 supra and accompanying text.

91. Of course, the alternative which offers the most benefits for the least costs, including environmental costs, is necessarily the preferred choice. In fact, any agency admission to the contrary would surely be arbitrary and capricious. 
accomplishment of the project. ${ }^{92}$ The reviewing court must consider whether the agency reasonably construed the statutes at issue and attributed the proper weight to the national policies involved. ${ }^{93}$ If environmental protection is a far stronger policy than that which would be served by a continuation of the project, then the administrator's choice of courses of action is limited to those choices in which benefits from the project substantially outweigh the environmental detriments. The alternatives available to the administrator will depend on the relative strength of the competing policy offsetting the policy in favor of environmental protection. As set forth in Overton Park, ${ }^{94}$ the standard of review to be applied is whether the agency or administrator could reasonably believe that its choice fell within the permissive range.

Once a court determines that the choice made could reasonably be thought to fall within the permissible range, the court will review the decision only to determine whether the agency's choice was reached in an arbitrary and capricious manner. ${ }^{95}$ As the Supreme Court cautioned in Overton Park, this is a narrow standard of review which does not allow the courts to substitute their judgment for the agency's. ${ }^{96}$ This standard does, lowever, require a care-

92. Section 101(b) states that the agency "must use all practicable means, consistent with other essential considerations of national policy . . . " 42 U.S.C. $\S 4331$ (b) (1970) (emphasis added). For the full text of this section, see note 9 supra. The word "essential" would seem to indicate that the environmental policy is a strong one. Professor Jaffe comments that

[i]n the present climate of public opinion, which is being more and more reflected in statutes such as NEPA, the courts in the exercise of their lawmaking function should give environmental considerations a very ligh priority. Jaffe, Book Review, 84 HARv. L. REv. 1562, $1563-64$ (1971) (footnotes omitted).

93. Although the APA commands that "the reviewing court shall determine all relevant questions of law . . ., 5 U.S.C. $\$ 706$ (1970), the courts do give some deference to an agency's interpretation and application of a statute. However, it is the courts which ultimately must decide what interpretation would best serve the congressional intent. Cf. Citizens To Preserve Overton Park, Inc. v. Volpe, 401 U.S. 402, 415-17 (1971). This would seem particularly to be true of a statute in which the construing agency has not been given primary administrative responsibility.

For a discussion of the law-fact distinction as it relates to NEPA, see Sive, supra note 8 , at $619-31$.

94. See note 75 supra and accompanying text.

95. 401 U.S. at 416.

96. Id. Jaffe points out that

if a legislature chooses to confer a power-be it a power to build roads or to license the use of the public domain-on an administrative officer, there is simply no basis for the exercise of the power by a court. The doctrine of limited judicial review expresses this fundamental premise of our Con- 
ful inquiry into the facts to ascertain whether the agency: (1) considered all relevant factors and (2) did not make a clear error of judgment in reaching its decision. ${ }^{97}$ An admission by an agency or a finding by the court that an agency has chosen a course of action which does not maximize benefits (including environmental benefits) as against costs (including technical, environmental, and monetary costs) would clearly be arbitrary and capricious. Further, if the balancing by the agency, reflected in its decision, clearly gave insufficient weight to environmental costs, this agency action would have to be set aside as arbitrary and capricious. In sum, then, this very relaxed standard leaves the agency broad discretion to find facts and engage in a balancing of the costs and benefits to accrue from any choice of action.

stitution. It is on this premise that a court is limited to questions of law, abuse of discretion, or lack of adequate evidence. Jaffe, Book Review, 84 HARV. L. REV. 1562, 1568 (1971).

97. 401 U.S. at 416. It might be argued, however, that this second-level determination should be subject to the substantial-evidence standard of review; alternatively, if the proposed construction of the Act given in the text is rejected, it might be argued that the entire agency determination should be subject to a substantialevidence test. Section 706(2)(E) of the APA, which requires the court to set aside an agency decision "unsupported by substantial evidence in a case . . . reviewed on the record of an agency hearing provided by statute," provides the necessary authority. 5 U.S.C. $\S 706(2)(E)(1970)$. The Supreme Court in Overton Park said that a record that is the basis of agency action is the fundamental requirement for the substautial-evidence test. 401 U.S. at 415. Section 102(2)(C) of NEPA requires an agency to prepare a "detailed statement" whenever a major federal undertaking may have a significant impact on the environment. 42 U.S.C. $\S 4332$ (2)(C) (1970). The production of an impact statement, which the courts have rigorously enforced as a procedural requirement of NEPA, could provide the basis for review under this standard. See note 12 supra and accompanying text.

Recently, the courts have required agencies to include opposing viewpoints in their impact statements. See, e.g., Committee for Nuclear Responsibility, Inc. v. Seaborg, 463 F.2d 783 (D.C. Cir. 1971). For a fuller discussion of recent court decisions on the required contents of an impact statement, see Memorandum for Agency and General Liaison on National Euvironmental Pohicy Act Matters, 2 EII ENVIronmental L. ReP. 46162 (1972). In Hanly v. Mitchell, 460 F.2d 640, 647 (2d Cir), cert denied, Hanly v. Kleindienst, 409 U.S. 990 (1972), the court noted that NEPA requires "federal agencies to affirmatively develop a reviewable environmental record ...." In Hanly v. Kleindienst, F.2d (2d Cir. 1972), the court went even further in demanding a reviewable record. These holdings, however, relate only to the section 102(2)(C) threshold determination of whether to issue an impact statement. But the Court of Appeals for the Eighth Circuit recently said that "the formal impact study supphes a convenient record for courts to use in reviewing agency decisions on the merits to determine if they are in accord with the substantive policies of NEPA." Euvironmental Defense Fund, Inc. v. Froehlke, - F.2d -, - (8th Cir. 1972). Therefore, this impact statement might be considered a record upon which the agency bases its action. If so, the agency findings might be subject to a substantial-evidence test. 